\title{
日本のストリートダンスにおける傷害調査
}

\author{
佐藤 菜穂子
}

\section{Injury surveillance in street dance in Japan}

\author{
Nahoko Sato \\ 名古屋学院大学リハビリテーション学部理学療法学科, †480-1298 愛知県瀬戸市上品野町 1350 (Department of Physical \\ Therapy, Faculty of Rehabilitation Science, Nagoya Gakuin University, 1350 Kamishinano-cho, Seto, Aichi 480-1298, Japan)
}

Received : April 5, 2018 / Accepted: August 29, 2018

\begin{abstract}
Although street dance quickly became popular in Japan, and the population of street dancers is increasing, there is limited information on injuries sustained during street dance in Japan. The purpose of this study was to investigate the epidemiology of injuries in street dancers in Japan. One hundred and ninety-five Japanese street dancers (92 intermediate, 35 advanced, and 68 expert dancers) participated in this study. A questionnaire survey concerning the injuries sustained during dancing was conducted over a 3-month period. The main results were: (1) Sixty-one dancers reported a total of 72 injuries, and injury rate was 0.56 per 1000 players-hours; (2) Ankle injuries accounted for $45.8 \%$ of the reported injuries; (3) Dancing proficiency level was related to the occurrence of injury, and the occurrence was significantly higher for the expert dancers; (4) The duration of warm-up was related to the occurrence of pains. These findings provide fundamental information that may contribute to the development of injury prevention in street dance.
\end{abstract}

Jpn J Phys Fitness Sports Med, 67(6): 431-437 (2018)

Keywords : street dance, injuries, hip-hop dance

\section{緒言}

ストリートダンスは, ヒップホップダンス, ロッキン グダンス, ブレイキングダンス, ポッピングダンス, ジャ ズダンスなどのダンスを総称したものである ${ }^{1)}$.クラシッ クバレエやモダンダンスなどのダンスと比べると歴史が 浅く, 1960年代アメリカでヒップホップの文化とともに 発展したダンスである。日本では，1980年頃からテレビ 番組などでストリートダンスが放送されるようになり， 2012年には, 中学校保健体育においてヒップホップダン スを含むダンスの授業が必修化された。また高等学校に おいてストリートダンスを行うダンス部の数も年々増加 していると報告されている2．ストリートダンスは日本 で急速に人気が広がっており，2018年のユースオリン ピック競技大会にブレイキングダンスが採用されること となったため, ユース世代のストリートダンサーが今後 も増えていくと予想される.

日本において若者を中心に流行しているストリートダ ンスは, 中学・高校においても他のスポーツと同様に部 活動としても行われることが多くなっているが, 高校名 ンス部や中学校での保健体育の授業では, 専門性をもっ た指導者が不足していることが問題となっている ${ }^{2,3)}$.さ
らには，ウォーミングアップや筋力トレーニングなどの 基礎·基本練習を行っていないケースも報告されており ${ }^{2)}$, 系統立った指導がなされていないと推測できる。

サッカーやバスケットボールのような競技人口が多い スポーツでは，これまで多くの傷害調査が実施され，問 題となる傷害が抽出されてきた ${ }^{4-6)}$ 。 また傷害を有する 競技者をなるべく早期に発見するために，傷害のリスク ファクターを抽出する試みがなされている7,8). しかしダ ンスにおいては, 傷害調査に関する報告は非常に少ない. 特にストリートダンスにおける傷害の調査は, 国外で実 施された研究がいくつか報告されているだけで1,9,10), 十 分な情報が得られているとは言えない. 先にも述べたが, 日本国内においては専門性をもった指導者の不足，系統 立った指導内容が確立されていないといった問題が報告 されていることから ${ }^{2,3)}$, 日本においてストリートダンス で発生する傷害も, 比較的指導者や指導内容が整備され た国外で実施された先行研究とは異なる可能性が考えら れる。

今後, 学校授業だけでなくオリンピック等の競技種目 として発展していくためには，ストリートダンス特有の 傷害を把握し, 傷害のリスクファクターを検討すること は非常に有用であると考えられる，以上のことから，本 
研究では, ストリートダンスで生じる傷害の種類, 経験 年数との関係, およびウォーミングアップとの関係を明 らかにすることを目的とした。

\section{方法}

調査対象者 日本ストリートダンススタジオ協会に所属 するダンス専門学校のダンサーを調查対象とした，本研 究は名古屋学院大学医学研究倫理委員会の承認を得て 行った（承認番号2017-2）.

方法 調查期間は, 平成 29 年 7 月から 9 月までの 3 ケ月 間であった。調查は，独自に作成した質問用紙を用いて 実施した（Table 1)。調査は各専門学校の代表者に依頼 し, 同意が得られた場合, 専門学校の代表者に質問用紙 を郵送した。調查対象者には，本研究の趣旨を書面にて 説明し，同意書への署名をもって調查協力に対する同意 を得たものとし，その後，質問用紙に回答をしてもらっ た。なお，本研究では，返送された質問用紙（返送率 $76.5 \% ） 216$ 件のうち，すべての質問項目に回答があっ た195名（男性59名, 女性 136 名, 年齢 $18.7 \pm 0.7$ 歳, 身長 $160.2 \pm 7.1 \mathrm{~cm}$, 体重 $51.4 \pm 8.1 \mathrm{~kg}$ ）を対象とした。

質問用紙の質問項目は，ダンサーの傷害調査を行った Ojofeitimi et al. ${ }^{1)}$ の質問項目を参考に, ダンサーの地位 (アマチュア・プロフェッショナル・指導者), 経験年数, 主要なダンスジャンル，コンテスト等での受賞経験の有 無, 1 週間当たりの練習時間, ウォーミングアップの時 間, 過去 1 年以内の傷害抢よび疼痛の有無について調査 を実施した（Table 1)。すべての質問項目に対する回答 は，ダンサーの自己申告とした，傷害および疼痛につい ては, ダンスによって発生したもののみを対象とした。 本研究では, National Collegiate Athletic Associationに よるInjury Surveillance Systemの定義 ${ }^{11)} よ り ， 1$ 日以 上練習もしくは舞台を休む期間があった傷害を対象と し，傷害ありと回答したダンサーには，傷害の種類，傷 害部位，練習休止期間について質問した。傷害部位につ いては，頭頸部・体幹・腰部 $/$ 骨盤・肩 ·上腕 $/$ 肘関節 · 前腕 $/$ 手関節 - 手 · 股関節 - 膝関節 $\cdot$ 大腿 $/$ 下腿 $\cdot$ 足関 節／足部に分類した ${ }^{1}$. 傷害の発生率は, 一人のダンサー が練習および舞台に参加した1,000 時間あたりの傷害の 発生件数を意味する 1,000 player-hoursの単位を用い, デー夕の統計学的安定性を得るために $95 \%$ 信頼区間（以 下，95\%CI）とともにそれぞれ算出した。また本研究では, 先行研究 ${ }^{1)}$ に基づき, 経験年数によってダンサーのダン スレベルを 3 群に分類した（5年以内: 中級者, 6-9 年： 上級者, 10 年以上：熟練者).

統計処理について，コンテスト等での受賞経験の有無 での経験年数の比較には対応のない $\mathrm{t}$ 検定を, ダンスレ ベル間での練習時間の比較には，一元配置分散分析およ
びTurkeyのpost hoc testを実施した。傷害発生の有無 とダンスレベルの関連, 疼痛発生の有無とウォーミング アップ時間の関連については $x^{2}$ 検定掞よび残差分析 ${ }^{12)}$ を行った，統計処理には，統計解析ソフトウェアIBM SPSS Statistic（ver. 25.0, IBM, USA）を用いて行い，有 意水準は $5 \%$ とした。

\section{結果}

対象195名中，192名がアマチュアダンサー， 3 名が プロフェッショナルダンサーで, ダンス指導者は 0 名で あった。平均経験年数は $7.2 \pm 4.7$ 年で, 経験年数によっ て分類したダンスレベルは，92名が中級者，35名が上級 者，68名が熟練者であった。195名中，56名（28.7\%）の ダンサーがコンテスト等での受賞経験のあるダンサーで あった，受賞経験があるダンサーは受賞経験がないダン サーよりも有意に経験年数が長かった $(\mathrm{p}<0.01)$. 全ダ ンサーの平均練習時間は $19.5 \pm 8.9$ 時間で，ダンスレベル によって練習時間に有意な差はなかった。ダンスジャン ルは $54.4 \%$ \%゙ヒップホップ, $41.0 \%$ がジャズ, $2.1 \%$ \%ブ レイキング, $1.5 \%$ がロッキング, $1.0 \%$ がポッピングの ダンサーであった（Table 2).

195名のうち，61名のダンサー $(29.7 \%)$ から 72 件の傷 害の報告があった．また 61 名のうち 9 名のダンサーから は複数箇所の傷害の報告があった. 傷害の発生率は, 0.56 [0.41-0.71（［］内は95\%CIを示す）であった.

傷害の発生部位では，33件（45.8\%）が足関節／足部 と最も多く，14件 (19.4\%) が腰部／骨盤，9件 (12.5\%) が大腿 /下腿， 7 件 (9.7\%) が膝関節， 4 件 (5.6\%) が 股関節， 3 件 (4.2\%) が頭頸部， 2 件 (2.8\%) が肩関節 であった（Table 3)。足関節／足部の傷害として報告さ れた 33 件のうち，14件は足関節捻挫であった。腰部 /骨 盤の傷害として報告された 14 件のうち，12件が腰部痛で あった。

傷害の有無とダンスレベルの関連について,$x^{2}$ 検定捛 よび残差分析を行ったところ, 中級者では傷害が少なく, 熟練者では傷害が有意に多く報告されたことが分かった $(\mathrm{p}<0.05$, Table 4$)$.

疼痛発生の有無とウォーミングアップ時間との関連に ついて， $x^{2}$ 検定抢よび残差分析を行ったところ, ウォー ミングアップ時間が 30 分以上の場合, 疼痛発生が有意に 少なくなることが分かった $(\mathrm{p}<0.05$, Table 5$)$.

\section{考察}

本研究で対象としたダンサーは，平均年齢が $18.7 \pm 0.7$ 歳，平均経験年数は $7.2 \pm 4.7$ 年であり，大部分が高等学 校に扣いてストリートダンスを行うダンス部の数が増 え始めた世代のダンサーであると考えられた ${ }^{21}$ 。本研究 では, Ojofeitimi et al. ${ }^{1{ }^{1}}$ の先行研究を参考に経験年数に 
Table 1. The questionnaire completed by dancers in this study

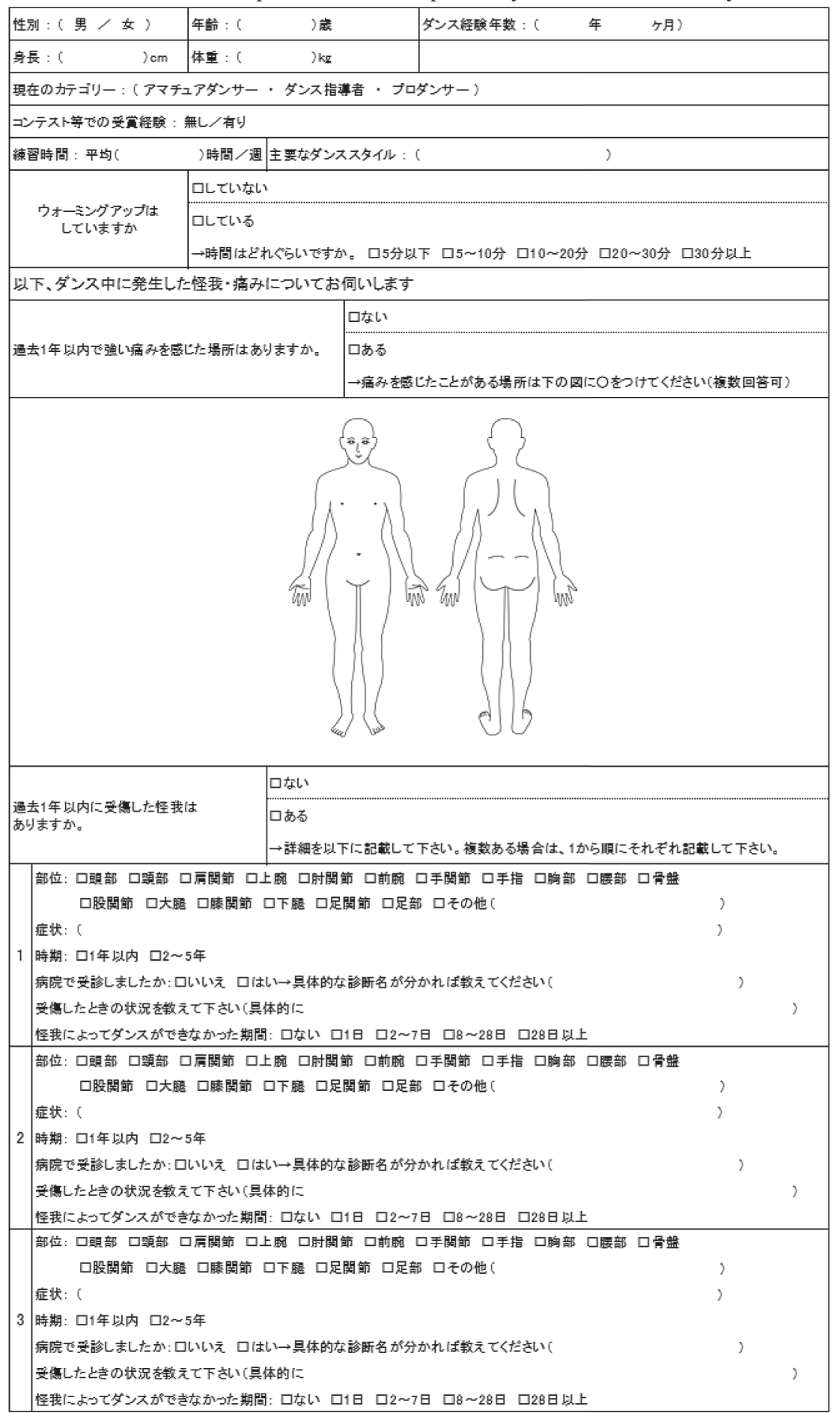

よりダンスレベルを分類したが，対象としたダンサー の $98.5 \%$ \%アアマチュアダンサーであったことから，ダン スレベルに偏りがあることが予想された。 しかし，ダン スレベルを判断できる指標の一つであるコンテストなど での受賞経験を有するダンサーは，受賞経験がないダン サーよりも経験年数が有意に長かったことから，本研究 において経験年数によるダンスレベルの分類は妥当であ ると考えた。

ストリートダンスにおける傷害を調査した先行研究 ${ }^{1)}$
では，傷害発生件数に関する報告はあったが，傷害発生 率は報告されていなかった。傷害の発生は個々のダン サーの練習時間などの影響を受けるため, 傷害発生率と して1,000 player-hoursが傷害調査の報告にはしばしば 用いられている ${ }^{13-16)}$ 。本研究におけるストリートダンス

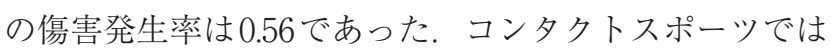
バスケットボールが4.16)， サッカーが5.6 ${ }^{17)}$ であり，体 操競技は 2.5 と報告されている ${ }^{18)}$. 一方ダンスでは, モダ ンダンスが $0.46^{15)}$ ，バレエが $0.62^{16)}$ と報告されているこ 
Table 2. Demographics

\begin{tabular}{|c|c|c|}
\hline & $\mathrm{N}(\mathrm{SD})$ & Percent of subjects \\
\hline Dancer & 195 & \\
\hline Male & 59 & 30.3 \\
\hline Female & 136 & 69.7 \\
\hline Height $(\mathrm{cm})$ & $160.2(7.1)$ & \\
\hline Weight $(\mathrm{kg})$ & $51.4(8.1)$ & \\
\hline Age (years) & $18.7(0.7)$ & \\
\hline Prize-winning dancers of competitions & 56 & 28.7 \\
\hline \multicolumn{3}{|l|}{ Years dancing (years) } \\
\hline All dancers & $7.2(4.7)$ & \\
\hline Prize-winning dancers & $9.4(4.5)$ & \\
\hline Non prize-winning dancers & $6.4(4.5)$ & \\
\hline Practice time (hours/week) & $19.5(8.9)$ & \\
\hline \multicolumn{3}{|l|}{ Dance level } \\
\hline Intermediate & 92 & 47.2 \\
\hline Advanced & 35 & 17.9 \\
\hline Expert & 68 & 34.9 \\
\hline \multicolumn{3}{|l|}{ Dance status } \\
\hline Amateur & 192 & 98.5 \\
\hline Professional & 3 & 1.5 \\
\hline Teacher & 0 & 0.0 \\
\hline \multicolumn{3}{|l|}{ Dance form } \\
\hline Hip-hop & 106 & 54.4 \\
\hline Jazz & 80 & 41.0 \\
\hline Breaking & 4 & 2.1 \\
\hline Locking & 3 & 1.5 \\
\hline Popping & 2 & 1.0 \\
\hline
\end{tabular}

Table 3. Injuries by anatomic region

\begin{tabular}{lrrr}
\hline & \multicolumn{1}{c}{ Area } & N & Percent of total \\
\hline Lower extremity & Foot/Ankle & 33 & 45.8 \\
& Shin/leg & 9 & 12.5 \\
& Knee & 7 & 9.7 \\
Trunk & Hip & 4 & 5.6 \\
& Lumbar/Pelvis & 14 & 19.4 \\
Head & Thorax & 0 & 0.0 \\
Upper extremity & Head/Neck & 3 & 4.2 \\
& Shoulder & 2 & 2.8 \\
& Arm/Elbow & 0 & 0.0 \\
& Forearm/Wrist & 0 & 0.0 \\
& Hand & 0 & 0.0 \\
& Total & 72 & 100.0 \\
\hline
\end{tabular}


Table 4. Dance level and occurrence of injury

\begin{tabular}{ccrr}
\hline \multirow{2}{*}{ Dance level } & & \multicolumn{2}{c}{ Injury } \\
\cline { 3 - 4 } Intermediate & $\mathrm{N}$ & No & Yes \\
& $\%$ & 78.3 & 21.7 \\
& Adjusted residual & $2.7^{*}$ & $-2.7^{*}$ \\
Advanced & $\mathrm{N}$ & 23 & 12 \\
& $\%$ & 65.7 & 34.3 \\
\multirow{2}{*}{ Expert } & Adjusted residual & -0.4 & 0.4 \\
& $\mathrm{~N}$ & 39 & 29 \\
& $\%$ & 57.4 & 42.6 \\
& Adjusted residual & $-2.5^{*}$ & $2.5 *$ \\
\hline Total & $\mathrm{N}$ & 134 & 61 \\
& $\%$ & 68.7 & 31.3 \\
\hline & & & ${ }^{*} \mathrm{p}<0.05$
\end{tabular}

Table 5. Pain and warming up time

\begin{tabular}{|c|c|c|c|c|c|c|c|}
\hline \multirow{2}{*}{ Pain } & & \multicolumn{6}{|c|}{ Warming up time (min) } \\
\hline & & 0 & $1-5$ & $6-10$ & $11-20$ & $21-30$ & $31-$ \\
\hline \multirow[t]{3}{*}{ No } & $\mathrm{N}$ & 0 & 0 & 8 & 16 & 19 & 22 \\
\hline & $\%$ & 0.0 & 0.0 & 12.3 & 24.6 & 29.2 & 33.8 \\
\hline & Adjusted residual & -0.7 & -1.5 & -0.7 & -1.5 & -0.5 & $3.4^{*}$ \\
\hline \multirow[t]{3}{*}{ Yes } & $\mathrm{N}$ & 1 & 2 & 21 & 46 & 43 & 17 \\
\hline & $\%$ & 0.8 & 1.5 & 16.2 & 35.4 & 33.1 & 13.1 \\
\hline & Adjusted residual & 0.7 & 1.0 & 0.7 & 1.5 & 0.5 & $-3.4^{*}$ \\
\hline \multirow[t]{2}{*}{ Total } & $\mathrm{N}$ & 1 & 2 & 29 & 62 & 62 & 39 \\
\hline & $\%$ & 0.5 & 1.0 & 14.9 & 31.8 & 31.8 & 20.0 \\
\hline
\end{tabular}

とから，ストリートダンスに扔ける傷害発生率は、コン タクトスポーツや体操競技と比べると非常に低く，他の 種類のダンスと同程度であることが分かった。

傷害の発生部位では，足関節／足部が $45.8 \%$ と最も多 く，モダンダンスに拈いて報告された $34 \%{ }^{16)}$ や，体操競 技に抢いて報告された $31.2 \%{ }^{19)}$ よりも高率であった。体 操競技の傷害を調査したKolt et al. ${ }^{19)}$ は, 頻回の着地動 作, また回転や捻りの要素が, 足関節／足部の傷害を引 き起こす要因になっているのではないかと述べている. ストリートダンスは，一定のリズムに乗って体幹・下肢 関節を屈曲伸展させ身体全体を上下に動かす基本的リズ 厶動作 ${ }^{20)} に$ に, 各種ステップを組み合わせて踊るダンスで あることから, 体操競技と同様の回転や捻りを伴った着 地動作も頻回に行われると考えられる。このストリート ダンスの動作特性により，足関節／足部に傷害が最も多
く発生すると考えられた。また，モダンダンスや体操競 技は，着地の衝撃を吸収するような床で実施されるが, ストリートダンスはそのような機能を持たない床で実施 されることが多い，さらには，練習環境が屋内の体育館 やスタジオであるとは限らず，夜間の路上などの暗い不 整地で練習をするダンサーも多く見られる ${ }^{1,2)}$. これらの 環境が，ストリートダンスにおいてモダンダンスや体操 競技よりも足関節／足部傷害の割合が多い要因であると 考えられた。

傷害の発生部位で次に多いのは $19.4 \%$ の腰部／骨盤で あり，そのほとんどを腰部痛が占めた。アスリートの腰 部痛に着目した研究は多くなされており,フットボー ルで $27 \%$ ，体操競技で $50 \%$ ，新体操で $86 \%$ の選手が腰 部痛を有していると報告されている ${ }^{21)}$. Hutchinson ${ }^{22)}$ は, 繰り返し行われる大きい速度での捻りや屈曲伸展が 
要求されるスポーツでは, 腰部傷害が発生する可能性が 高いと述べている，体操競技や新体操などはこれに当て はまると考えるが，ストリートダンスには，これらの競 技ほど大きい速度での捻りや過度な屈曲伸展を伴う動作 は含まれていない，一方，筋の柔軟性の低下と体幹の安 定性の低下が腰痛発生のリスクファクターであるとする Piazza et al. ${ }^{23)}$ の報告は, 本研究で腰痛の発生率が他の 部位と比べて高かった原因を説明できるかもしれない． つまり, 本研究で対象となったアマチュアダンサーの多 くは，専門的な知識をもつ指導者の下で筋の柔軟性や体 幹の安定性を得るための準備体操や基本練習を行わず, 各々が習得したいダンスムーブを模倣する練習に終始し ていた可能性がある.

さらに, 本研究では, 経験年数が長い熟練者ほど傷害 を多く報告した。体操競技では，オリンピック出場レベ ルのエリート競技者よりも，レベルの低いサブエリート 競技者において傷害が多いとする報告があり, サブエ リート競技者は技術基準の要求を満たすために，自身の スキルよりも高い技に挑戦することがその理由として述 ベられている ${ }^{19)}$. 本研究では経験年数によってダンスレ ベルを分類したが，先行研究のサブエリート競技者と同 様に, 経験年数が長い熟練者ほど高度な技に挑戦する機 会が多いと考えられ，それが本研究の熟練者において傷 害が多かった理由であると考えられた。しかしダンサー のスキルが向上すれば傷害の報告が少なくなることも考 えられるため, ダンスレベルと傷害発生の関係について は, プロフェッショナルとして活躍するスキルの高いダ ンサーを含めた, より多くのダンサーに扔いて詳細に調 査する必要があると考える.

また，ウォーミングアップを 30 分以上行ったダンサー では疼痛発生の報告が少なかった。ウォーミングアップ には様々な効果があり，傷害を予防できることが，いく つかの研究で明らかになっている ${ }^{24,25)}$ ，ストリートダン スでは, ウォーミングアップや筋力トレーニングなどの 基礎・基本練習を行っていないケースも報告されている ため ${ }^{2)}$, 本研究の結果から, 十分なウォーミングアップ を行うことで, 疼痛発生のリスクを減らすことができる 可能性が示唆された。しかし 1 時間の授業や，限られた 練習時間の中で実施するダンス部の活動において，30分 以上のウォーミングアップを実施することは現実的には 難しいと考えられる。 今後は, ウォーミングアップの内 容をより詳細に調査し, 効率的・効果的なウォーミング アップについても検討していく必要がある.

ストリートダンスに扔ける傷害の特徵として，傷害発 生率は他のダンスと同程度であったが，足関節／足部の 傷害の割合が他の種類のダンスよりも高く，その要因と して，ストリートダンスの動作特性や床面などの練習環 境の問題が考えられた，練習環境については，国外で実
施されたダンスに抒ける傷害の調査でも，指導者がいな い場所で練習することが多いことや，夜間の不整地で練 習することが問題として報告されている ${ }^{1,9)}$ 。 ストリー トダンスは, アメリカの公園や街頭などの路上でのパ フォーマンスが起源とされており ${ }^{26)}$ ，その背景が現在の 練習環境にも大きく影響していると考えられた。しかし, 中学校, 高等学校でもストリートダンスを行う機会が非 常に増えていることから, 練習環境の改善は傷害を予防 するために必要不可欠である。また傷害の予防には，よ り専門的な知識や基礎的な練習に関する情報を提供する ことも重要である.

本研究には 4 つの限界点がある。1つ目は, 対象の夕゙ ンサーを男女別に解析しなかったことであり，他のス ポーツのように ${ }^{27,28)}$, 性差が傷病発生にどのような影響 を与えるかを明らかにすることができなかった，2つ目 は，調查対象の数が少なかったことであり，ダンスレベ ルが傷害部位に影響するか否かといった，より詳細な解 析を行うことができなかった．3つ目は，ダンスによっ て発生した傷害および疼痛をダンサーの自己申告にて聴 取した際に，ダンス以外のスポーツ活動については聴取 しなかった点である。そのため，本研究で報告された傷 害拉よび疼痛に, ダンス以外のスポーツ活動が影響を与 えた可能性を否定することができない，4つ目は，傷害 発生時の詳細な状況の調査が不足していたことであり, 傷害が好発する動作や環境を明らかにすることができな かった

今後の目標として, より詳細な傷害発生のメカニズム を分析することにより，傷害予防の基礎的な情報を提供 することが必要であると考えられた。また，ダンサーの 筋力や関節可動域など，身体的な特徵や運動能力と傷 害との関係を調査することにより，有効なメディカル チェックを開発できると考えられた。

利益相反自己申告：申告すべきものはなし

\section{謝 辞}

本研究は名古屋学院大学研究助成（2017年度）を受けた ものである。

\section{文献}

1) Ojofeitimi S, Bronner $S$, Woo H. Injury incidence in hip hop dance. Scand J Med Sci Sports 22: 347-355, 2012.

2）中村なお 小, 勢畑多恵子, 布施典子：高等学校における ダンス部の活動実態及び部員の意識調査〜東京都に拀 ける急増するダンス部の現状と課題〜, 日本女子体育連 盟学術研究, 30: 69-79, 2014.

3）熊谷佳代, 中川裕紀子：岐阜県の中学校に打けるダンス 授業の現状と課題, 岐阜大学教育学部研究報告 教育実 践研究, 16: 21-28, 2014. 
4) Knowles SB, Marshall SW, Bowling JM, Loomis D, Millikan R, Yang J, Weaver NL, Kalsbeek W, Mueller FO. A prospective study of injury incidence among North Carolina high school athletes. Am J Epidemiol 164: 1209-1221, 2006.

5) Le Gall F, Carling C, Reilly T, Vandewalle H, Church $\mathrm{J}$, Rochcongar P. Incidence of injuries in elite French youth soccer players: a 10-season study. Am J Sports Med 34: 928-938, 2006.

6) Gomez E, DeLee JC, Farney WC. Incidence of injury in Texas girls' high school basketball. Am J Sports Med 24: 684-687, 1996.

7) Shambaugh JP, Klein A, Herbert JH. Structural measures as predictors of injury basketball players. Med Sci Sports Exerc 23: 522-527, 1991.

8) McGuine TA, Greene JJ, Best T, Leverson G. Balance as a predictor of ankle injuries in high school basketball players. Clin J Sport Med 10: 239-244, 2000.

9) Cho CH, Song KS, Min BW, Lee SM, Chang HW, Eum DS. Musculoskeletal injuries in break-dancers. Injury 40: 1207-1211, 2009.

10) Kauther MD, Wedemeyer C, Wegner A, Kauther KM, von Knoch M. Breakdance injuries and overuse syndromes in amateurs and professionals. Am J Sports Med 37: 797-802, 2009.

11) Dick R, Agel J, Marshall SW. National Collegiate Athletic Association Injury Surveillance System commentaries: introduction and methods. J Athl Train 42: 173-182, 2007.

12) Haberman SJ. The Analysis of Residuals in CrossClassified Tables. Biometrics 29: 205-220, 1973.

13) Allen N, Ribbans WJ, Nevill AM, Wyon MA. Musculoskeletal injuries in dance: A systematic review. Int $J$ Phys Med Rehabil 3: 252, 2014.

14) Harringe ML, Renström P, Werner S. Injury incidence, mechanism and diagnosis in top-level teamgym: a prospective study conducted over one season. Scand $J$ Med Sci Sports 17: 115-119, 2007.

15) Bronner S, Ojofeitimi S, Rose D. Injuries in a modern dance company: effect of comprehensive management on injury incidence and time loss. Am J Sports Med 31: 365-373, 2003.

16) Nilsson C, Leanderson J, Wykman A, Strender LE.
The injury panorama in a Swedish professional ballet company. Knee Surq Sports Traumatol Arthrosc 9: 242-246, 2001.

17) Emery CA, Meeuwisse WH, Hartmann SE. Evaluation of risk factors for injury in adolescent soccer: implementation and validation of an injury surveillance system. Am J Sports Med 33: 1882-1891, 2005.

18) Caine D, Knutzen K, Howe W, Keeler L, Sheppard L, Henrichs D, Fast J. A three-year epidemiological study of injuries affecting young female gymnasts. Phys Ther Sport 4: 10-23, 2003.

19) Kolt GS, Kirkby RJ. Epidemiology of injury in elite and subelite female gymnasts: a comparison of retrospective and prospective findings. Br J Sports Med 33: 312-318, 1999.

20) Sato N, Nunome H, Ikegami Y. Kinematic analysis of basic rhythmic movements of hip-hop dance: motion characteristics common to expert dancers. J Appl Biomech 31: 1-7, 2015.

21) Purcell L, Micheli L. Low back pain in young athletes. Sports Health 1: 212-222, 2009.

22) Hutchinson MR. Low back pain in elite rhythmic gymnasts. Med Sci Sports Exerc 31: 1686-1688, 1999.

23) Piazza M, Di Cagno A, Cupisti A, Panicucci E, Santoro G. Prevalence of low back pain in former rhythmic gymnasts. J Sports Med Phys Fitness 49: 297-300, 2009.

24) Small K, Mc Naughton L, Matthews M. A systematic review into the efficacy of static stretching as part of a warm-up for the prevention of exercise-related injury. Res Sports Med 16: 213-231, 2008.

25) Woods K, Bishop P, Jones E. Warm-up and stretching in the prevention of muscular injury. Sports Med 37: 1089-1099, 2007.

26) Sato N, Nunome H, Ikegami Y. Key features of hip hop dance motions affect evaluation by judges. I Appl Biomech 30: 439-445, 2014.

27) Backous DD, Friedl KE, Smith NJ, Parr TJ, Carpine WD Jr. Soccer injuries and their relation to physical maturity. Am J Dis Child 142: 839-842, 1988.

28) Zelisko JA, Noble HB, Porter M. A comparison of men's and women's professional basketball injuries. Am J Sports Med 10: 297-299, 1982. 